\title{
Сучасний тренд в операційному лікуванні геморою - закрита гемороїдектомія без швів. Наш клінічний досвід
}

\begin{abstract}
Мета роботи: покращити результати операційного лікування геморою з використанням різного електрохірургічного обладнання. Матеріали і методи. Проаналізовано результати лікування 81 пацієнта з гемороєм II-IV стадії впродовж 2016-2021 pp. на базах кафедри хірургії № 3 Національного медичного університету імені О. О. Богомольця, яким виконали гемороїдектомію 3 використанням електрохірургічного обладнання (апарати ALAN Elsy360M+, Патонмед EKB3-300, Liga Sure).

Результати досліджень та їх обговорення. Структурний розподіл пацієнтів за статтю: серед них було 45 (55,6 \%) жінок та 36 $(44,4$ \%) чоловіків. Середній вік пацієнтів склав 37,2 року. У 27 (33,3 \%) осіб був геморой II ступеня, у 48 (59,3 \%) - III ступеня, у 6 (7,4 \%) - IV ступеня. Всі операційні втручання виконано в умовах операційної під спинномозковою або загальною анестезією. У жодного пацієнта не знадобилося будь-якого додаткового інтраопераційного гемостазу. Середня тривалість операційного втручання склала 17,4 хвилини (з коливаннями від 12 до 31 хвилини). Термін перебування в стаціонарі становив 2-3 доби, а період амбулаторного доліковування - 12-21 день. Працездатність пацієнтів відновлювалася через 10-12 діб. Лише 5 (6,17 \%) хворих вказували на періодичний дискомфорт та свербіж в ділянці прямої кишки через 4 тижні після виконання операційного втручання. Вираження больового синдрому, оціненого за візуальною аналоговою шкалою, в середньому склало 3,7 бала, що відповідає незначному болю або толерантному болю при рухах. Найвираженіший біль у пацієнтів спостерігали на 3-4 доби післяопераційного періоду, що, ймовірно, зумовлено відторгненням коагуляційного некрозу з ранових поверхонь у цей період. У 5 (6, 17 \%) пацієнт у післяопераційному періоді встановлено рефлекторну затримку сечі. Віддалені результати у строки від 12 до 18 місяців простежені у 44 (54,3 \%) хворих. Повне одужання і відновлення якості життя настало у 42 ( 95,45 \%) хворих. Причинами незадовільної оцінки якості життя у 2 (4,55 \%) пацієнтів були хронічні закрепи і не були безпосередньо пов'язані 3 проведеним операційним втручанням. Ми не спостерігали рецидиву захворювання за зазначений період спостереження у жодного хворого. Звуження анального каналу було виявлено у 2 (4,5 \%) пацієнтів. Клінічну симптоматику та стенозування вдалося повністю усунути пальцевим бужуванням у поєднанні з медикаментозними препаратами. Отже, гемороїдектомія, виконана електрохірургічним обладнання, є безпечним, ефективним та сучасним операційним втручанням, яке практично не потребує використання шовного матеріалу. Застосування методики суттєво зменшує операційну крововтрату, скорочується час проведення операції, зменшується її вартість.
\end{abstract}

Ключові слова: проктологія; геморой; закрита гемороїдектомія без швів; ускладнення гемороїдектомії; електрозварювання тканин.

Постановка проблеми і аналіз останніх досліджень та публікацій. Геморой - це одне з найпоширеніших захворювань прямої кишки [1-15], частота якого становить 130-145 осіб на 1000 дорослого населення, а рівень потреби в госпіталізації досягає 30-40 \%. Питома вага хвороби в загальній структурі ректальної патології досі складає 34-41 \%, уражуючи пацієнтів працездатного віку $[1,2,5,6]$. Захворювання призводить не тільки до тимчасової непрацездатності в період загострень, але й суттєво знижує якість життя.

До сьогодні найефективнішим методом операційного лікування геморою все ще залишається гемороїдектомія [1-15]. Вона є однією з найвиконуваніших аноректальних операцій, вважається нескладною процедурою, проте післяопераційний перебіг є затяжним, а ускладнення досить розповсюджені та іноді тяжкі (рання затримка сечі, інфекції сечовивідних шляхів, післяопераційна кровотеча, що деколи вимагає повторної операції, пізній анальний стеноз, який потребує болісної пальцевої девульсії або хірургічної корекції ). Отже, хірургіч- ні методи втручання, що позбавлені перерахованих післяопераційних недоліків, є дуже актуальними при операціях на тканинах аноректальної ділянки. Добрі гемостатичні характеристики показав метод високочастотної монополярної електрокаутеризації. Розтин тканин таким електроножем супроводжується надійним гемостазом, але недоліком цього інструменту є утворення великої зони термічного опіку тканин в ділянці проведення розрізу, а отже, вираженого згодом післяопераційного больового синдрому і тривалого терміну регенерації ранової поверхні, що утворилася [1-3].

На противагу, рани, завдані радіохвильовим скальпелем або лазером, навпаки, характеризуються малою травматичністю розрізу та теплового ушкодження навколишніх тканин, але потребують додаткових методів гемостазу при їх застосуванні у хірургічному лікуванні геморою [1-3].

Тому вибір оптимальної, надійної, відносно недорогої методики, яка легка у використанні та освоєнні, залишається надзвичайно актуальним сьогодні [1-15]. 


\section{З ДОСВІДУ РОБОТИ}

3 метою зменшення операційної травматизації і покращення післяопераційного одужання дедалі частіше для видалення кавернозної тканини прямої кишки використовують сучасне електрохірургічне обладнання з ефектом зварювання біологічних тканин, яке по суті забезпечує закриту гемороїдектомію без швів [3, 4, 13, 15].

Мета роботи: покращити результати операційного лікування геморою з використанням різного електрохірургічного обладнання.

Матеріали і методи. Проаналізовано лікування 81 пацієнта з гемороєм II-IV стадії впродовж 2016-2021 pр. на базах кафедри хірургії № 3 НМУ імені О. О. Богомольця, яким виконали гемороїдектомію з використанням електрозварювального обладнання (апарати ALAN Elsy360M+, Патонмед EKB3-300, Liga Sure). Структурний розподіл хворих: у 61 (75,3 \%) особи використовували ALAN Elsy360M+, y 11 (13,6 \%) - Патонмед ЕКВ3-300, у 9 (11,1 \%) Liga Sure. Жінок було у 45 (55,6 \%) та чоловіків - 36 (44,4 \%). Середній вік хворих склав 37,2 року. У 27 (33,3 \%) пацієнтів діагностували геморой 2-го ступеня, у 48 (59,3\%) - 3-го ступеня, у $6(7,4 \%)$ - 4-го ступеня. Основними симптомами були випадання гемороїдальних вузлів, кровотеча різного ступеня (траплялися у всіх пацієнтів), біль (діагностували у 21 особи). Передопераційна підготовка - стандартна.

Anapam ALAN Elsy360M+ (рис. 1) виробництва Alan Electronic Systems Private Limited має монополярні режими різання та коагуляції, біполярні режими різання та коагуляції, а також режим електролігування (заварювання судин); максимальна потужність роботи коагулятору - 400 Вт.

Електрозварювання - процес подачі струму певної форми, частоти та потужності на біологічні тканини, під час якого відбувається денатурація колагену зі спаюванням протилежних прошарків, при цьому внутрішня еластична мембрана залишається майже недоторканою.

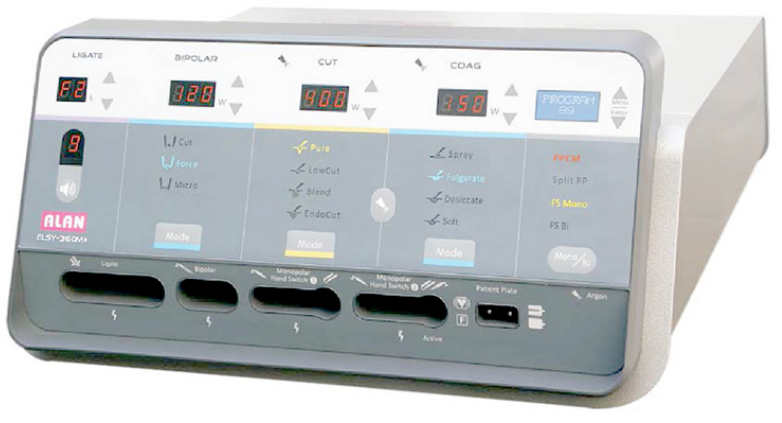

Рис. 1. Апарат ALAN Elsy360M+.
Функція електрозварювання, яка реалізується цим апаратом, полягає у використанні технології розрахунку імпедансу (опору тканини) в режимі реального часу. Декілька мікроконтролерів відстежує, автоматично діагностує та миттєво налаштовує потужність струму на виході, відповідно до варіацій густоти та імпедансу тканини. Завдяки цьому для кожної ділянки тканини підбираються індивідуально необхідні струми, які не надають надмірного впливу та не пошкоджують їі, що сприяє швидшому одужанню пацієнтів після операції.

EKB3-300 Патонмед (рис. 2) - це апарат, призначений для високочастотного зварювання, коагуляції та різання м'яких живих тканин у хірургії. Виконання операційних втручань безкровне, швидке, 3 безлігатурним перекриттям судин i відсутністю кровотечі, без некротизуючого опіку, зручне для хірурга і малотравматичне для пацієнта. Вплив на тканини здійснюється тільки між електродами інструмента, без ушкодження прилеглих тканин та органів. Зменшується крововтрата на 60-85\%. Скорочується тривалість операції на 20-50 \%. Післяопераційна реабілітація швидша і більш повноцінна. Встановлено, що електрозварний шов стійкий до ферментативного розсмоктування, залишається в тканинах тривалий період часу, достатній для успішної регенерації тканин. Водночас як відповідь на наявність зварного шва в організмі не виникають імунопатологічні процеси ні на загальному, ні на місцевому рівні.

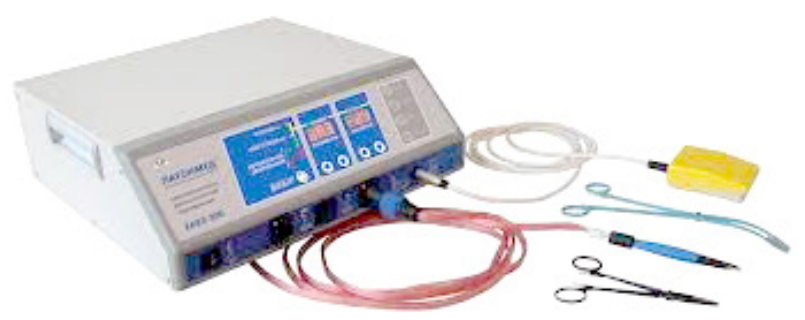

Рис. 2. Апарат ЕКВ3-300 Патонмед.

Електротермічна система Liga Sure (рис. 3) розроблена для коагуляції та перетину судин до 7 мм у діаметрі, забезпечує контрольовану подачу енергії до тканин та надійний гемостаз. Механізм впливу на тканини полягає в розплавленні колагену та еластину. Міцність “завареної зони”, що складається з частково денатурованого протеїну, порівнювана 3 міцністю прошитої тканини. Окрім цього, немає необхідності у виділенні та лігуванні судинної ніжки гемороїдального вузла. Тому в літературі гемороїдектомію, яку виконують за допомогою апарата LigaSure, часто називають 


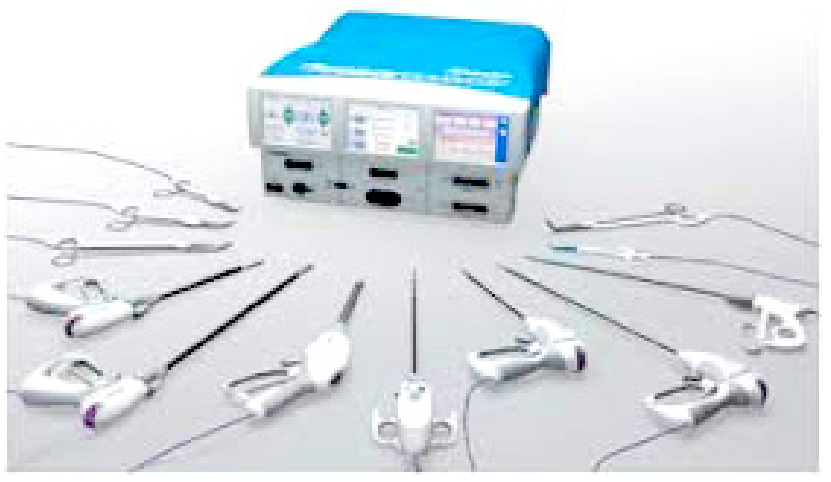

Рис. 3. Апарат Liga Sure.

“закритою безшовною гемороїдектомією” $[4,13$, 15]. Електричний струм подається циклами (пакетами). Після закінчення циклу відбувається охолодження та “зварювання” тканин. Цикли подачі електроструму чергуються з паузами до моменту білкової денатурації. Увесь процес займає близько п'яти секунд. Тканини, розміщені між бранш інструменту (до 5 см), “зварюються” разом, потім їх необхідно перетнути. Термічна дія проникає в тканини на 2 мм.

Техніка закритої безшовної гемороїдектомії

Після анестезії здійснюється ревізія анального каналу. Верхівку гемороїдального вузла на 3 годинах захоплюють затискачем. Потім поетапно ззовні до середини затискачем апарата виконують біполярну електрокоагуляцію тканин, розташованих між браншами (рис. 4). На цьому етапі необхідно бути обережними, щоб не захопити в затискач волокна внутрішнього сфінктера. При цьому відбувається денатурація білка, утворюється щільна колагенова плівка, так званий зварний

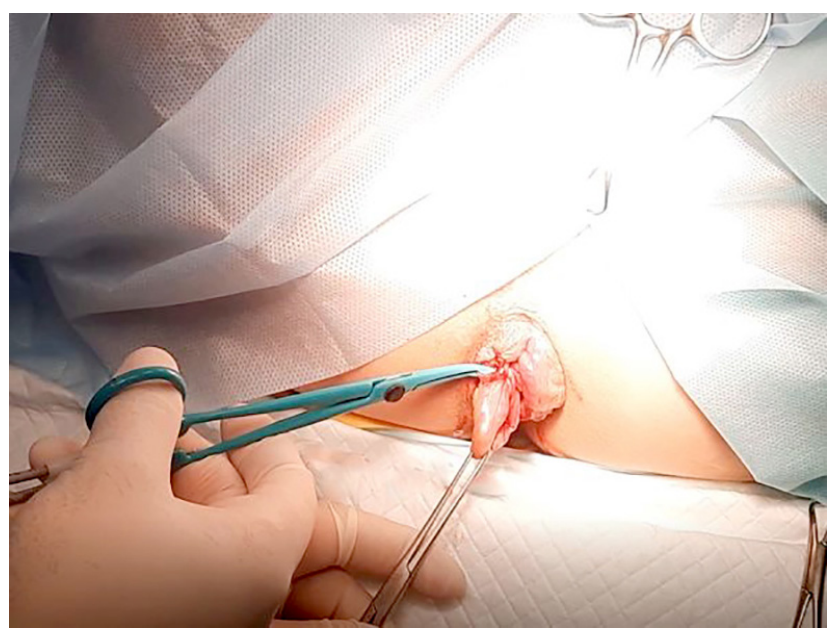

a шов, який відмежовує рану від зовнішнього середовища, запобігаючи первинному інфікуванню рани. Висічення гемороїдального вузла робимо хірургічними ножицями по зовнішньому краю “зварного” шва. 3 метою підвищення надійності гемостазу судинну ніжку коагулюють двічі. Аналогічно видаляють гемороїдальні вузли на 7 та 11 годинах. Іноді необхідно висікати додаткові гемороїдальні вузли. Зашивання післяопераційних ран не проводиться.

Результати досліджень та їх обговорення. Оцінка безпосередніх результатів проведених операцій включала: оцінку кількості післяопераційних ускладнень, інтенсивності та тривалості больового синдрому, швидкості регенерації ран, тривалості перебування пацієнтів у стаціонарі, термін відновлення працездатності хворих. Об'єктивізація інтенсивності післяопераційного больового синдрому здійснювалася за допомогою десятибальної візуально-аналогової шкали та потреби у наркотичних та ненаркотичних анальгетиках. 3 метою оцінки швидкості загоєння ран та відновлення працездатності хворих запрошували на контрольні огляди в післяопераційному періоді. Повторні ендоскопічні дослідження виконано усім пацієнтам через 4-5 тижнів після операційного втручання. При цьому зазначено, що терміни загоєння ран та відновлення тонусу сфінктерного апарата складали чотири-п'ять тижнів.

Bсі операційні втручання виконано в умовах операційної, під спинномозковою або загальною анестезією. Жоден пацієнт не потребував додаткового інтраопераційного гемостазу. Середня тривалість операційного втручання склала 17,4 хв (3 коливаннями від 12 до 31 хв). Термін перебування

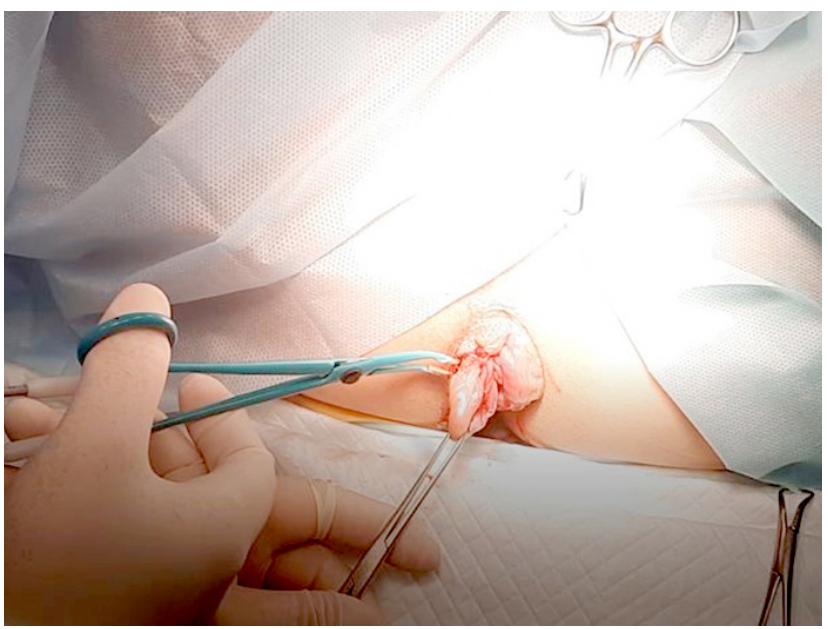

б

Рис. 4. Техніка операції. 


\section{З ДОСВІДУ РОБОТИ}

у стаціонарі становив 2-3 доби, а період амбулаторного доліковування - 12-21 день. Помірний больовий синдром при виписуванні зі стаціонару зберігався у 18 (22,22 \%) пацієнтів, жоден з них не потребував повторної госпіталізації. У 23 (28,4%) осіб зберігався набряк та незначні кров'янисті виділення при акті дефекації впродовж 2 тижнів, які успішно піддавалися амбулаторному медикаментозному лікуванню. Працездатність пацієнтів відновлювалася через 10-12 діб. Лише 5 (6,17 \%) осіб спостерігали періодичний дискомфорт та свербіж у ділянці прямої кишки через 4 тижні після виконання операційного втручання. Вираження больового синдрому за візуальною аналоговою шкалою в середньому склала 3,7 бала, що відповідає незначному болю або толерантному болю при рухах. Найвираженіший больовий синдром у пацієнтів спостерігали на 3-4 доби післяопераційного періоду, що ймовірно зумовлено відторгненням коагуляційного некрозу з ранових поверхонь у цей термін. У 5 (6, 17 \%) осіб у післяопераційному періоді спостерігали рефлекторну затримку сечі.

Віддалені результати у строки від 12 до 18 місяців простежені у 44 (54,3 \%) хворих.

Результати лікування оцінювали за такими критеріями:

1. Наявність рецидиву захворювання.

2. Наявність віддалених ускладнень проведеного лікування - стриктур анального каналу, рубцевих деформацій періанальної ділянки, нориць та ін.

3. Оцінка якості життя оперованих хворих.

3 метою вивчення якості життя прооперованих пацієнтів ми використовували методику анкетування.

Повне одужання і відновлення життєвої якості настало 42 (95,45 \%) хворих. Причинами незадовільних оцінок якості життя у інших 2 (4,55 \%) пацієнтів були хронічні закрепи і не були безпосередньо пов'язані з проведеним операційним втручанням. Консервативна терапія дала змогу корегувати розлади дефекації в цієї категорії хворих.

Загалом ми не спостерігали рецидиву захворювання за зазначений період спостереження у жодного пацієнта. Таке ускладнення, як звужен- ня анального каналу, виявлено у 2 (4,5 \%) осіб, оперованих із застосуванням Liga Sure. Розвиток стриктур в обох хворих спостерігали у період через 4 тижні після операційного втручання. Клінічні прояви характеризувалися болем при дефекації, зміною форми випорожнень. Треба зазначити, що розвиток стриктур встановили в пацієнтів, яким гемороїдектомія доповнювалася редукцією гемороїдальної тканини в шкірно-слизових містках, що залишаються. Клінічну симптоматику та звуження вдалося повністю усунути пальцевим бужуванням у поєднанні з медикаментозними препаратами. При контрольному візиті через 3 місяці у обох хворих проявів не було.

Висновки. Гемороїдектомія, яка виконана електрохірургічним обладнанням, є закритою методикою, при якій відбувається коагуляція тканин гемороїдального вузла та судин між браншами інструменту, що запобігає контакту ранової поверхні $з$ навколишніми тканинами. Мінімальний термічний вплив у ході хірургічного втручання, а також відсутність в анальному каналі шовного матеріалу супроводжується менш вираженим больовим синдромом, що сприяє скороченню потреби в анальгетиках та зниження частоти рефлекторної затримки сечовипускання. Застосування методики суттєво зменшує операційну крововтрату (проводиться в практично безкровних умовах), скорочується тривалість операції, зменшується ії вартість, а міцність операційного зварювального шва підтверджує відсутність післяопераційних кровотеч у наших спостереженнях. Всі перераховані вище дані вказують на можливість широкого застосування електрохірургічного обладнання для операційного лікування геморою, методика $є$ безпечною, ефективною, відносно недорогою та сучасним операційним втручанням.

Перспективи подальших досліджень. Використання даного методу операційного втручання при геморої II-IV стадії є перспективним, потребує подальшого аналізу отриманих віддалених результатів з метою їх порівняння з іншими хірургічними втручаннями.

\section{СПИСОК ЛІТЕРАТУРИ}

1. Шелыгин Ю. А. Основные направления организации специализированной колопроктологической медицинской помощи / Ю. А. Шелыгин, А. В. Веселов, А. А. Сербина // Колопроктология. - 2017. - № 1. - С. 76-81.

2. Шелыгин Ю. А. Справочник колопроктолога / Ю. А. Шелыгин, Л. А. Благодарный. - Москва : Литера, 2012. - 596 с.

3. Геморроидэктомия без швов / Л. А. Благодарный, Ю. А. Шелыгин, Л. А. Хмылов, В. Х. Соттаева // Колопроктология. - 2006. - № 3. - С. 8-12.

4. Chung Y.-C. Clinical experience of sutureless closed hemorrhoidectomy with Ligasure. / Y.-C. Chung, H.-J. Wu // Dis. Colon Rectum. - 2003. - No. 46. - P. 87-92. 


\section{З ДОСВІДУ РОБОТИ}

5. Randomized clinical trial of Ligasure vs. conventional diathermy in hemorrhoidectomy / E.Franklin, S. Seetharam, J. Lowny [et al.] // Dis. Colon Rectum. - 2003. - No. 46. - P. 13-80.

6. Meta-analysis of stapled hemorrhoidopexy vs LigaSure hemorrhoidectomy / J. Yang, P. Cui, H. Han, D. Tong // World Journal of Gastroenterology. - 2013. - No. 19. - P. 4799-4807.

7. Ligasure versus Ferguson hemorrhoidectomy in the treatment of hemorrhoids: a meta-analysis of randomized control trials / L. Xu, H. Chen, G. Lin, Q. Ge // Surgical Laparoscopy, Endoscopy \& Percutaneous Techniques. - 2015. - No. 25. - P. 106-110.

8. The American Society of Colon and Rectal Surgeons Clinical Practice Guidelines for the Management of Hemorrhoids / B. Davis, S. Lee-Kong, J. Migaly [et al.] // Dis. Colon Rectum. - 2018. - No. 61. - P. 1-284.

9. Comparison of stapled haemorrhoidopexy with traditional excisional surgery for haemorrhoidal disease (eTHoS): a pragmatic, multicentre, randomised controlled trial / A. Watson, J. Hudson, J. Wood [et al.] // Lancet. - 2016. - No. 388. - P. 23-75.

10. Comparison of surgical procedures implemented in recent years for patients with grade III and IV hemorrhoids: a network

\section{REFERENCES}

1. Shelygin, Yu.A., Veselov, A.V., \& Serbina, A.A.(2017). Osnovnye napravleniya organizatsii spetsializirovannoy koloproktologicheskoy meditsinskoy pomoshchi [The main directions of the organization of specialized coloproctological medical care]. Koloproktoligiya - Coloproctology, 1, 76-81 [in Russian].

2. Shelygin, Yu.A., \& Blagodarny, L.A. (2012). Spravochnik koloproktologa [Coloproctologist's guide]. Moscow: Litera [in Russian]. 3. Blagodarny, L.A., Shelygin, Yu.A., Khmylov, L.A., \& Sottaeva, V.Kh. (2006). Gemorroidektomiya bez shvov [Hemorrhoidectomy without stitches]. Koloproktoligiya - Coloproctology, 3, 8-12 [in Russian].

4. Chung, Y.-C., \& Wu, H.-J. (2003). Clinical experience of sutureless closed hemorrhoidectomy with Ligasure. Dis. Colon Rectum, 46, 87-92.

5. Franklin, E., Seetharam, S., \& Lowny, J. (2003). Randomized clinical trial of Ligasure vs. conventional diathermy in hemorrhoidectomy. Dis. Colon Rectum, 46, 13-80.

6. Yang, J., Cui, P., Han, H., \& Tong, D. (2013). Meta-analysis of stapled hemorrhoidopexy vs LigaSure hemorrhoidectomy. World Journal of Gastroenterology, 19, 4799-4807.

7. Xu, L., Chen, H., Lin, G., \& Ge, Q. (2015). Ligasure versus Ferguson hemorrhoidectomy in the treatment of hemorrhoids: a meta-analysis of randomized control trials. Surgical Laparoscopy, Endoscopy \& Percutaneous Techniques, 25, 106-110.

8. Davis, B., Lee-Kong, S., \& Migaly, J. (2018). The American Soci- meta-analysis / T. Du, S. Quan, T. Dong, Q. Meng // Int. J. Colorectal Dis. - 2019. - No. 34. - P. 1000-1001.

11. Systematic review and network meta-analysis comparing clinical outcomes and effectiveness of surgical treatments for haemorrhoids / C. Simillis, S. N. Thoukididou, A. P. Slesser [et al.] // BSJ. - 2015. - Vol. 102, No. 13. - P. 1603-1618.

12. Simillis C. Systematic review and network meta-analysis comparing clinical outcomes and effectiveness of surgical treatments for haemorrhoids / C. Simillis// Br. J. Surg. - 2015. No. 102. - P. 1603-1618.

13. Comparison of hemorrhoidectomy by LigaSure with conventional Milligan Morgan’s hemorrhoidectomy / B. Nighat, A. Foad, J. Farhat [et al.] // Cochrane Database Syst. Rev. - 2016. - No. 10. - P. 323-324.

14. Roervik H. D. Minimal open hemorrhoidectomy / H. D. Roervik // Tech. Coloproctol. - 2019. - No. 23. - P. 73-77.

15. Ligasure hemorrhoidectomy: Updates on complications after an 18-year experience / M. Rho, A. Guida, M. Materazzo [et al.] // Reviews on Recent Clinical Trials. - 2021. - Vol. 16, No. 1. P. $101-108$. ety of Colon and Rectal Surgeons Clinical Practice Guidelines for the Management of Hemorrhoids. Dis. Colon Rectum, 61, 1-284.

9. Watson, A., Hudson, J., \& Wood, J. (2016). Comparison of stapled haemorrhoidopexy with traditional excisional surgery for haemorrhoidal disease (eTHoS): a pragmatic, multicentre, randomised controlled trial. Lancet, 388, 23-75.

10. Du, T., Quan, S., Dong, T., \& Meng, Q. (2019). Comparison of surgical procedures implemented in recent years for patients with grade III and IV hemorrhoids: a network meta-analysis. Int. J. Colorectal Dis., 34, 1000-1001.

11. Simillis, C., Thoukididou, S.N., \& Slesser, A.P. (2015). Systematic review and network meta-analysis comparing clinical outcomes and effectiveness of surgical treatments for haemorrhoids. BSJ, 102 (13), 1603-1618.

12. Simillis, C. (2015). Systematic review and network meta-analysis comparing clinical outcomes and effectiveness of surgical treatments for haemorrhoids. Br. J. Surg., 102, 1603-1618.

13. Nighat, B., Foad, A., \& Farhat, J. (2016). Comparison of hemorrhoidectomy by LigaSure with conventional Milligan Morgan’s hemorrhoidectomy. Cochrane Database Syst. Rev., 10, 323-324. 14. Roervik, H.D. (2019). Minimal open hemorrhoidectomy. Tech. Coloproctol., 23. 73-77.

15. Rho, M., Guida, A., \& Materazzo, M. (2021). Ligasure hemorrhoidectomy: Updates on complications after an 18-year experience. Reviews on Recent Clinical Trials, 16 (1), 101-108. 


\author{
P. V. IVANCHOV, Y. Y. PERESH, O. I. LISSOV, V. M. SYDORENKO \\ O. Bohomolets National Medical University, Kyiv
}

\title{
CURRENT TREND IN SURGICAL TREATMENT OF HEMORRHOID-CLOSED HEMOROIDECTOMY WITHOUT SUTURES. OUR CLINICAL EXPERIENCE
}

The aim of the work: to improve the results of surgical treatment of hemorrhoids using various electrosurgical equipment.

Materials and Methods. The treatment of 81 patients with hemorrhoids grade 2-4 for the period from 2016-2021 was analyzed. They were treated on the basis of the Department of Surgery No. 3, O. Bohomolets National Medical University. Hemorrhoidectomy using electrosurgical equipment (ALAN Elsy360M+, Patonmed EKVZ-300, Liga Sure) was conducted.

Results and Discussion. Structure of patients by sex: among them there were 45 (55.6\%) women and $36(44.4 \%)$ men. The mean age of patients was 37.2 years. 27 (33.3 \%) patients had a hemorrhoid grade 2, 48 (59.3\%) - grade 3, in 6 (7.4 \%) - grade 4. All surgeries were performed in the operating room, under spinal or general anesthesia. No patient required any additional intraoperative hemostasis. The average duration of surgery was 17.4 minutes (ranging from 12 to 31 minutes). The length of stay in the hospital was $2-3$ days, and the period of outpatient treatment - 12-21 days. The patients' ability to work was restored after 10-12 days. Only 5 (6.17\%) of the all patients reported recurrent discomfort and itching in the rectum 4 weeks after surgery. The severity of the pain syndrome, assessed on a visual analog scale, averaged 3.7 points, which corresponds to slight pain or tolerable pain when moving. The most pronounced pain in patients was observed on day 3-4 of the postoperative period, which is probably due to the rejection of coagulation necrosis from wound surfaces during this period. In $5(6.17 \%)$ patients in the postoperative period reflex urinary retention was noted. Long-term results in the period from 12 to 18 months were observed in 44 (54.3 \%) patients. Complete recovery and restoration of quality of life occurred in 42 (95.45 \%) patients. The reasons for unsatisfactory quality of life assessments in the other $2(4.55 \%)$ patients were chronic constipation and were not directly related to surgery. We did not report a recurrence of the disease during this observation period in any patient. Narrowing of the anal canal was detected in 2 (4.5 \%) patients. Clinical symptoms and stenosis were completely eliminated by finger devulsion in combination with drug treatment. Thus, hemorrhoidectomy performed with electrosurgical equipment is a safe, effective and modern surgical procedure that requires virtually no use of suture material. The application of the technique significantly reduces surgical blood loss, reduces the time of the operation, reduces its cost.

Key words: proctology; hemorrhoids; closed hemorrhoidectomy without sutures; complications of hemorrhoidectomy; electric tissue welding. 